\title{
Morphological, Genetic, and Pathogenic Characterization of Colletotrichum acutatum, the Cause of Anthracnose of Almond in Australia
}

\author{
Suzanne F. McKay, Stanley Freeman, Dror Minz, Marcel Maymon, \\ Margaret Sedgley, Graham C. Collins, and Eileen S. Scott
}

First, sixth, and seventh authors: The University of Adelaide, School of Agriculture, Food and Wine, PMB 1 Glen Osmond, South Australia, 5064, Australia; second and fourth authors: Department of Plant Pathology, and third author: Institute for Soil, Water and Environmental Sciences, ARO, The Volcani Center, P.O. Box 6, Bet Dagan 50250, Israel; and fifth author: The University of New England, Faculty of the Arts and Sciences, Armidale, New South Wales, 2351, Australia.

Accepted for publication 3 April 2009.

\begin{abstract}
McKay, S. F., Freeman, S., Minz, D., Maymon, M., Sedgley, M., Collins, G. C., and Scott, E. S. 2009. Morphological, genetic, and pathogenic characterization of Colletotrichum acutatum, the cause of anthracnose of almond in Australia. Phytopathology 99:985-995.

Almond anthracnose was reported for the first time in Australia in 1998 and has since been observed in all of the major almond-growing regions. The organism causing anthracnose was confirmed as Colletotrichum acutatum using taxon-specific polymerase chain reaction (PCR). Three main morphotypes of $C$. acutatum from almond in Australia were identified (namely, pink, orange, and cream colony color) and the optimum temperature for mycelial growth of representative isolates was $25^{\circ} \mathrm{C}$. Australian isolates of $C$. acutatum were more similar morphologically to the pink subpopulation of $C$. acutatum from California than to the gray Californian subpopulation and the isolates of Colletotrichum

from Israel. Inter-simple-sequence-repeat (ISSR) PCR analysis revealed that the majority of Australian isolates shared an identical banding pattern whereas Australian isolates of $C$. acutatum from almond were distinct from isolates of the pink and gray subpopulations of $C$. acutatum from almond in California and of Colletotrichum spp. from almond in Israel. Sequence analysis of the internally transcribed spacer (ITS1-2) ribosomal DNA region of representative isolates differed from the results of ISSRPCR in that polymorphisms were revealed among isolates, indicating that some genetic variation may be present. Pathogenicity experiments on detached leaves and fruit revealed pathogenic variation among representative isolates of $C$. acutatum from almond in Australia, California, and Israel; however, all isolates tested caused disease. Distinct subgroups among Australian isolates of $C$. acutatum from almond were not supported on the basis of morphology, mycelial growth rates, ISSR-PCR, and pathogenicity.
\end{abstract}

Anthracnose caused by Colletotrichum spp. affects many crops worldwide (51). Anthracnose on almond was first reported in Italy (6) and subsequently in California $(9,16,23)$ and Israel (40). In Australia, anthracnose on almond was first reported in the Southern Vales region of South Australia (SA) in 1998 by Hall et al. (22). The disease has since been confirmed in all of the major almond-growing regions of Australia, and economically significant infection (up to $80 \%$ of fruit on a tree) has been reported (31). Anthracnose on almond in Australia is characterized by sunken orange lesions on young infected fruit, which generally shrivel, die, and remain on the tree throughout the season. Infected leaves show water-soaked lesions, yellowing, wilting, and then marginal necrosis. Infected twigs, spurs, and branches up to $5 \mathrm{~cm}$ in diameter die back, resulting in loss of fruitful wood and tree decline $(3,31)$.

In California and Australia, the pathogen causing anthracnose on almond has been identified as Colletotrichum acutatum J. H. Simmonds $(3,22)$. In Israel, C. gloeosporioides (Penz.) Penz. \& Sacc. was identified initially as the cause of anthracnose on

Corresponding author: S. McKay;

E-mail address: suzanne.mckay@adelaide.edu.au

* The $\boldsymbol{e}$-Xtra logo stands for "electronic extra" and indicates that the online version contains information showing the complete ITS1-2 sequences of the isolates examined.

doi:10.1094/PHYTO-99-8-0985

(C) 2009 The American Phytopathological Society almond (40) but more recent DNA-based identification indicates that the pathogen belongs to C. acutatum $(16,18)$.

Classification of Colletotrichum spp. on the basis of morphological and cultural features $(7,46)$ failed to resolve relationships among several species, including $C$. acutatum, due to overlapping morphological characteristics and wide host range. Lardner et al. (26) suggested that $C$. acutatum J. H. Simmonds is a subspecific group within the broader $C$. acutatum complex and Freeman et al. (19) referred to this group as $C$. acutatum sensu Simmonds. DNA-based methods are now routinely used in conjunction with morphological characteristics to identify and characterize Colletotrichum spp., including those from almond $(16,19,20,44)$.

Two distinct subpopulations have been identified among isolates of $C$. acutatum from almond in California on the basis of morphological and cultural characteristics, and DNA fingerprints obtained by arbitrary-primed polymerase chain reaction (ap-PCR) (16). In contrast, isolates of Colletotrichum spp. from almond in Israel are homogeneous with respect to morphology, cultural characteristics, vegetative compatibility group analysis, and banding patterns following ap-PCR $(17,18)$. Isolates of $C$. acutatum from almond in Australia have not been characterized with respect to morphological and cultural features, pathogenicity, and genetic variation, and it is not known whether these isolates differ from isolates from almond in California and Israel. These factors may have implications for management and control measures in Australia.

The research described here was undertaken to characterize isolates of $C$. acutatum from almond in Australia and to compare 
them with reference isolates from almond in California and Israel, and Colletotrichum spp. from other plants in Australia.

\section{MATERIALS AND METHODS}

Fungal cultures, isolation methods, and growth conditions. Almond plant material suspected by growers of having anthracnose was collected from all the major almond-growing regions of Australia, except Western Australia, in a survey carried out in 2001. Material was surface sterilized in a $1 \%$ solution of commercial bleach (White King, sodium hypochlorite, 42 g/liter) for $3 \mathrm{~min}$, rinsed twice in sterile distilled water (SDW), and blotted dry, then incubated in a humid chamber at $\approx 22^{\circ} \mathrm{C}$ in natural daylight for up to 14 days. Hyphal tips were transferred aseptically with a needle onto potato dextrose agar (PDA) (Difco Laboratories, Detroit) acidified with lactic acid ( $1 \mathrm{ml} / \mathrm{liter})$ and incubated at $25^{\circ} \mathrm{C}$ in darkness; then, single spore-derived cultures were established. Isolates were identified by morphology as described by Dyko and Mordue (13) and Cannon (7) and representative isolates (CSL-1687, CSL-1688, CSL-1689, CSL-1691, CSL-1690, CSL-1314, CSL-1315, CSL-1317, CSL-1318, CSL-1298, and DAR-72407) were deposited in culture collections of the Central Science Laboratory (CSL), Sand Hutton, United Kingdom and the Agricultural Scientific Collection Unit (DAR), Orange, New South Wales, Australia. Cultures were maintained as spore suspensions in $15 \%$ glycerol at $-80^{\circ} \mathrm{C}$. Isolates used in this study are listed in Table 1; those accessioned at CSL and DAR or obtained from California and Israel were designated reference isolates.

TABLE 1. Isolates of Colletotrichum spp. used in this study

\begin{tabular}{|c|c|c|c|c|c|c|c|}
\hline Species & Isolate code (EMBL accession) & Origin & Host & $\begin{array}{l}\text { Sample } \\
\text { size }\end{array}$ & Clade $^{a}$ & ISSR $^{b}$ & Type $^{\mathrm{c}}$ \\
\hline Colletotrichu & $\begin{array}{l}\text { DAR-72407,e, W1, W2, W4p, W4m, } \\
\text { W5p, W5L, W5m, W6, W7, W17, W24, } \\
\text { W26, W29, W31, W32, W33, W34, } \\
\text { W36, W38, W39, W43, W44, W45, } \\
\text { W47, W55, W64, W65, W66, W77, } \\
\text { W87, W100, W122, W128, W129, } \\
\text { W136, W143, W147, W154, W155, } \\
\text { W156, W157, W158, W159, W160, } \\
\text { W162, W163, W164, W165, W166, } \\
\text { W167, W168, W169, W170, W172, } \\
\text { W173, W174, W176, W177, W178, } \\
\text { W179, W181, W183, W184, W185, } \\
\text { W186, W188, W189, W190 }\end{array}$ & $\begin{array}{l}\text { Willunga, South Australia } \\
\text { (SA) }\end{array}$ & Prunus dulcis & 69 & nt & 1 & Pink \\
\hline C. acutatum & $\begin{array}{l}\text { CSL-1689 }{ }^{\mathrm{f}, \mathrm{g}}(\mathrm{EU} 670080), \mathrm{W} 16^{\mathrm{f}} \\
(\mathrm{EU} 670081), \mathrm{W} 153^{\mathrm{f}}(\mathrm{EU} 670085)\end{array}$ & Willunga, SA & P. dulcis & 3 & IV & 1 & Pink \\
\hline C. acutatum & $\mathrm{W} 169 \mathrm{~b}, \mathrm{~W} 184 \mathrm{~b}$ & Willunga, SA & P. dulcis & 2 & nt & 1 & Orange \\
\hline C. acutatum & CSL-1315, & Munno Para Downs, SA & P. dulcis & 1 & nt & 1 & Orange \\
\hline C. acutatum & CSL-1318 d,f,g (EU670083) & Angle Vale, SA & P. dulcis & 1 & I & ndc & Orange \\
\hline C. acutatum & $\mathrm{S} 68^{\mathrm{d}}$ & Unknown, Australia & P. dulcis & 1 & nt & 1 & Orange \\
\hline C. acutatum & CSL-1688 & Nangiloc, Victoria (Vic) & P. dulcis & 1 & IV & 1 & Orange \\
\hline C. acutatum & $\begin{array}{l}\text { CSL-1687 } 7^{\mathrm{d}, \mathrm{g}}, \mathrm{W} 76, \mathrm{~W} 107, \mathrm{~W} 117, \mathrm{~W} 162 \mathrm{a}, \\
\text { W169a, W171, W180 }\end{array}$ & Willunga, SA & P. dulcis & 8 & nt & 1 & Cream \\
\hline C. acutatum & CSL-1314 & SA & P. dulcis & 1 & nt & 1 & Cream \\
\hline C. acutatum & $\begin{array}{l}\text { CSL-1691, MPD1, MPD2, MPD3, } \\
\text { MPD4, MPD5, MPD7 }\end{array}$ & Munno Para Downs, SA & P. dulcis & 7 & nt & 1 & Pink \\
\hline C. acutatum & CSL-1690 d,f,g (EU670079) & Angle Vale, SA & P. dulcis & 1 & IV & 1 & Pink \\
\hline C. acutatum & $\mathrm{S} 43^{\mathrm{f}}(\mathrm{EU} 670082)$ & Angle Vale, SA & P. dulcis & 1 & C. boninense & 1 & Pink \\
\hline
\end{tabular}

${ }^{a}$ Designated clade from internal transcribed spacer sequence analysis; $\mathrm{nt}=$ not tested.

b Inter-simple-sequence-repeat (ISSR) cluster. In all, 67 isolates were used for ISSR polymerase chain reaction; ndc = no determined cluster or clade.

c Colony morphology type; 69 isolates were used for morphological characterization.

d Provided by Barbara Hall, South Australian Research and Development Institute, South Australia (SA), Australia.

e Deposited with the Agricultural Scientific Collection Unit, Orange, New South Wales (NSW), Australia.

f Sequenced by the authors.

g Deposited with the Central Science Laboratory, Sand Hutton, York, United Kingdom.

h Provided by the Volcani Center, Bet Dagan, Israel.

i Provided by Jim Adaskaveg and Helga Förster, University of California, Riverside.

j Sequenced by Freeman et al. 2001 (19).

k Provided by Gavin Ash, Charles Sturt University, NSW.

${ }^{l}$ Provided by Ru Huang, Charles Sturt University, NSW.

${ }^{\mathrm{m}}$ Sequenced by Talhinhas et al. 2005 (48).

${ }^{\mathrm{n}}$ Provided by Andrew Watson, Yanco Agricultural Institute, NSW.

o Sequenced by Hagedorn et al. 2000 (direct submission, unpublished).

p Sequenced by Martin and García-Figueres 1999 (30).

q Sequenced by Denoyes-Rothan et al. 2003 (11).

${ }^{r}$ Sequenced by Nirenberg et al. 2002 (35).

s Provided by Nancy Cunningham, South Australian Research and Development Institute, SA.

t Sequenced by Afanador-Kafuri et al. 2003 (4).

" Sequenced by Talhinhas et al. 2002 (47).

v Sequenced by Lotter et al. 2005 (27).

${ }^{w}$ Sequenced by Moriwaki et al. 2002 (34).

x Sequenced by Travanty et al. 1998 (EMBL, direct submission, unpublished).

y Sequenced by Moriwaki et al. 2003 (33).

${ }^{z}$ Sequenced by Farr et al. 2006 (14).

aaprovided by Mary Cole, Monash University, Victoria, and Richard Lardner, the University of Adelaide, SA. 
Morphological characterization. Macroscopic and microscopic characteristics were examined for 118 isolates of $\mathrm{Col}$ letotrichum, comprising 99 isolates of C. acutatum from almond in Australia, 10 of $C$. acutatum from both gray and pink subpopulations on almond in California, 7 of Colletotrichum spp. from almond in Israel, and 2 of $C$. gloeosporioides from orange in Australia. All isolates were subcultured onto PDA from conidia suspensions stored at $-80^{\circ} \mathrm{C}$. Cultures were grown in the dark at $25^{\circ} \mathrm{C}$ for 10 days; then, a 5-mm-diameter plug of mycelium from the colony margin was placed in the center of a $90-\mathrm{mm}$ petri dish containing PDA. Three replicate plates were prepared for each isolate and incubated in the dark at $25^{\circ} \mathrm{C}$ for 14 days, and morphological and colony characteristics recorded.

Color was based on the mycological color chart of Raynor (36). Conidia were mounted in lactoglycerol; the shape, length, and width of 50 conidia were determined; and mean length and width were calculated for each isolate. The conidia were assigned to one of three shape categories as described by Smith and Black (42). Cultures of US-1776, an isolate from the gray subpopulation of $C$. acutatum in California, did not produce conidia.

Taxon-specific PCR. Isolation and purification of fungal DNA. DNA was extracted from mycelia grown for 5 days in potato dextrose broth (Difco Laboratories) and purified as described by Rodriguez and Yoder (37) and Freeman et al. (19), except that $10 \mu \mathrm{l}$ of RNAse A $(10 \mathrm{mg} / \mathrm{ml})$ was added to the $1 \mathrm{ml}$ of lysis buffer. DNA was then suspended in $80 \mu \mathrm{l}$ of Tris-EDTA buffer (10 $\mathrm{mM}$ Tris-HCl, $1 \mathrm{mM}$ EDTA, $\mathrm{pH}$ 8.0) and diluted to $\approx 20 \mathrm{ng} / \mu \mathrm{l}$.

PCR amplification. Taxon-specific amplification was performed on the isolates tested in this study using the universal primer internal transcribed spacer (ITS)4 (53) coupled with

TABLE 1. (continued from preceding page)

\begin{tabular}{|c|c|c|c|c|c|c|c|}
\hline Species & Isolate code (EMBL accession) & Origin & Host & $\begin{array}{l}\text { Sample } \\
\text { size }\end{array}$ & Clade $^{\mathrm{a}}$ & $\mathrm{ISSR}^{\mathrm{b}}$ & Type $^{c}$ \\
\hline C. acutatum & S66 & Angle Vale, SA & P. dulcis & 1 & nt & 1 & Pink \\
\hline C. acutatum & $\mathrm{S} 44^{\mathrm{d}}$ & Western Australia (WA) & P. dulcis & 1 & nt & 1 & Pink \\
\hline C. acutatum & CSL-1317 d,g & Unknown, Australia & P. dulcis & 1 & nt & 1 & Pink \\
\hline \multirow[t]{2}{*}{ C. acutatum } & ALM-US-3Ph, ALM-US-6B ${ }^{\mathrm{h}}$, ALM-US- & & & & & & \\
\hline & $9^{\mathrm{h}}$, ALM-US-11 ${ }^{\mathrm{h}}, \mathrm{US}-1732^{\mathrm{i}}, \mathrm{US}-1796^{\mathrm{i}}$ & California, USA & P. dulcis & 6 & nt & 2 & Pink \\
\hline C. acutatum & ALM-US-4, & California, USA & P. dulcis & 1 & I & 2 & Pink \\
\hline C. acutatum & ALM-US-12 & California, USA & P. dulcis & 1 & nt & 2 & Cream \\
\hline C. acutatum & US-1813i,f (EU670086) & California, USA & P. dulcis & 1 & III & 4 & Gray \\
\hline C. acutatum & US-1776 & California, USA & P. dulcis & 1 & nt & 4 & Gray \\
\hline Colletotrichum sp. & ALM-KSH-10 ${ }^{\mathrm{h}, \mathrm{j}}(\mathrm{AF} 207791)$ & Israel & P. dulcis & 1 & III & 3 & Gray \\
\hline \multirow[t]{2}{*}{ Colletotrichum sp. } & $\begin{array}{l}\text { ALM-NRB-3DK }{ }^{\mathrm{h}}, \text { ALM-BZR-8L } \\
\text { ALM-GZT-1F } \\
\text { ALM-GVA-6A }\end{array}$ & & & & & & \\
\hline & ALM-GOZ-42B ${ }^{\mathrm{h}}$, ALM-NA-3P & Israel & P. dulcis & 7 & nt & 3 & Gray \\
\hline C. acutatum & $\mathrm{P} 1^{\mathrm{k}}$ & New South Wales (NSW) & Pistacia sp. & 1 & nt & 1 & Orange \\
\hline C. acutatum & $\mathrm{SE} 37^{\mathrm{d}}, \mathrm{OL}^{\mathrm{d}}, \mathrm{OL}^{\mathrm{d}}$ & SA & Olea europaea & 3 & nt & 1 & Pink \\
\hline C. acutatum & $\mathrm{OL} 2^{\mathrm{d}}$ & SA & O. europaea & 1 & nt & ndc & Gray \\
\hline C. acutatum & NSW $1^{1}$ & Hunter Valley, NSW & O. europaea & 1 & nt & ndc & Orange \\
\hline C. acutatum & PT231 ${ }^{\mathrm{m}}(\mathrm{AJ} 749695)$, PT250 ${ }^{\mathrm{m}}(\mathrm{AJ} 49700)$ & Portugal & O. europaea & 2 & III & nt & nt \\
\hline C. acutatum & PT227m (AJ749694) & Portugal & O. europaea & 1 & IV & nt & nt \\
\hline C. acutatum & PT135m (AJ749683) & Portugal & O. europaea & 1 & II & nt & nt \\
\hline C. acutatum & DAR-75574, & ? NSW & Vitis vinifera & 1 & nt & ndc & Gray \\
\hline C. acutatum & CSL-1298 ${ }^{\mathrm{d}, \mathrm{g}}$ & SA & Persea sp. & 1 & nt & ndc & Orange \\
\hline C. acutatum & $\mathrm{Bb} 1^{\mathrm{n}}$ & ? NSW & Vaccinium sp. & 1 & nt & ndc & Gray \\
\hline C. acutatum & BBA $68396^{\circ}(\mathrm{AJ} 301905)$ & Unknown & Vaccinium sp. & 1 & nt & ndc & nt \\
\hline C. acutatum & $\mathrm{S}^{2} 3^{\mathrm{d}}$ & The Adelaide Hills, SA & Fragaria sp. & 1 & nt & ndc & Gray \\
\hline C. acutatum & TUT-5954h,j (AF207794) & Israel & $\begin{array}{c}\text { Fragaria } \times \\
\text { ananassa }\end{array}$ & 1 & nt & ndc & Orange \\
\hline C. acutatum & CECT20120p (AF090853), & Spain & $F . \times$ ananassa & 1 & II & nt & nt \\
\hline C. acutatum & IMI345026j (AF272789) & Spain & F. $\times$ ananassa & 1 & III & nt & nt \\
\hline C. acutatum & BBA $67866^{\circ}(\mathrm{AJ} 301950)$ & Germany & F. $\times$ ananassa & 1 & II & nt & nt \\
\hline C. acutatum & PCH8j (AF272788) & South Carolina, USA & Prunus persica & 1 & I & nt & nt \\
\hline \multirow[t]{2}{*}{ C. acutatum } & $\mathrm{HV} 8 \mathrm{C}^{\mathrm{j}}(\mathrm{AF} 272782)$ & Israel & Anemone & & & & \\
\hline & & & coronaria & 1 & I & nt & $\mathrm{nt}$ \\
\hline C. acutatum & ANE-NL12A ${ }^{\mathrm{j}}(\mathrm{AF} 272781)$ & Netherlands & A. coronaria & 1 & I & nt & nt \\
\hline C. acutatum & BJS Tomatoq (AF489565) & United States & $\begin{array}{l}\text { Lycopersicon } \\
\text { esculentum }\end{array}$ & 1 & III & nt & nt \\
\hline C. acutatum & BBA62124r (AJ301924) & Kenya & Coffea arabica & 1 & IV & nt & nt \\
\hline C. acutatum & BBA $71371^{\circ}(\mathrm{AJ} 301982)$ & Unknown & Cyclamen sp. & 1 & $\mathrm{~V}$ & nt & nt \\
\hline C. gloeosporioides & $\mathrm{S} 54^{\mathrm{d}}, \mathrm{Or} 1^{\mathrm{s}}$ & Australia & Citrus sp. & 2 & nt & ndc & Gray \\
\hline C. gloeosporioides & AVO-37-4B ${ }^{\mathrm{h}, \mathrm{j}}(\mathrm{AF} 207792)$ & Israel & Persea americana & 1 & C. gloeosporioides & ndc & Gray \\
\hline C. gloeosporioides & AVO-58 & Israel & P. americana & 1 & nt & ndc & Gray \\
\hline C. gloeosporioides & Man-53t (AF521198) & Colombia & $\begin{array}{l}\text { Mangifera } \\
\text { indica }\end{array}$ & 1 & C. gloeosporioides & nt & nt \\
\hline Colletotrichum sp. & Man-76 (AF521204) & Colombia & M. indica & 1 & C. boninense & nt & nt \\
\hline Colletotrichum sp. & Pass-62u (AF521203) & Colombia & Passiflora sp. & 1 & C. boninense & $\mathrm{nt}$ & nt \\
\hline Colletotrichum sp. & $45^{\mathrm{u}}(\mathrm{AJ} 313178)$ & Portugal & Citrus sp. & 1 & C. gloeosporioides & nt & nt \\
\hline Colletotrichum sp. & $9^{\mathrm{u}}(\mathrm{AJ} 311391)$ & Canada & Lupinus sp. & 1 & $\mathrm{~V}$ & nt & nt \\
\hline Colletotrichum sp. & TNOS3 $^{u}(\mathrm{AJ} 300558)$ & Portugal & Lupinus sp. & 1 & II & nt & nt \\
\hline C. lupini & BBA $71249^{\circ}$ (AJ301959) & Canada & Lupinus sp. & 1 & $\mathrm{~V}$ & nt & nt \\
\hline C. lupini var. setosum & SHK 2148v (DQ174694) & South Africa & Lupinus sp. & 1 & $\mathrm{~V}$ & nt & nt \\
\hline C. orbiculare & MAFF $306589^{\mathrm{w}}(\mathrm{AB} 042309)$ & Japan & Cucumis sativus & 1 & ndc & nt & nt \\
\hline C. gramincola & $\mathrm{DR} 1^{\mathrm{x}}(\mathrm{AF} 059676)$ & United States & Роа аппиа & 1 & ndc & nt & nt \\
\hline C. boninense & MAFF $306100^{y}(A B 042313)$ & Japan & Coelogyne sp. & 1 & C. boninense & nt & nt \\
\hline C. boninense & DQ286170 (AR375) & China & Bambusa sp. & 1 & C. boninense & nt & nt \\
\hline Eutypa lata & $\mathrm{M} 280^{\mathrm{aa}}$ & Vic & Vitis vinifera & 1 & nt & ndc & nt \\
\hline
\end{tabular}


species-specific primers for $C$. acutatum (CaInt2) (GGGGAAGCCTCTCGCGG) or C. gloeosporioides (CgInt) (GGCCTCCCGCCTCCGGGCGG) $(32,43)$. PCR amplifications were performed in a total volume of $20 \mu \mathrm{l}$, comprising 10 to $20 \mathrm{ng}$ of genomic DNA; $50 \mathrm{mM} \mathrm{KCl} ; 10 \mathrm{mM}$ Tris- $\mathrm{HCl} ; 0.2 \mathrm{mM}$ each dATP, dCTP, dGTP, and dTTP; $1.5 \mathrm{mM} \mathrm{MgCl}$; 1 unit of Taq DNA polymerase (Promega Corp., Madison, WI); and $0.5 \mu \mathrm{M}$ ITS4 primer coupled with either $0.5 \mu \mathrm{M} C a$ Int 2 or $0.5 \mu \mathrm{M} C g$ Int primers. The DNA was amplified in a thermocycler (PTC-100; MJ Research, Watertown, MA), starting with $5 \mathrm{~min}$ of denaturation at $95^{\circ} \mathrm{C}$ followed by 30 cycles of $30 \mathrm{~s}$ at $95^{\circ} \mathrm{C}, 30 \mathrm{~s}$ at $60^{\circ} \mathrm{C}$, and $90 \mathrm{~s}$ at $72^{\circ} \mathrm{C}(18)$. Amplification products were separated in agarose gels $(1.5 \%, \mathrm{wt} / \mathrm{vol})$ in $1 \times$ Tris-acetate EDTA buffer ( $40 \mathrm{mM}$ Tris-acetate, $1 \mathrm{mM}$ EDTA), subjected to electrophoresis at $80 \mathrm{~V}$ for $2.5 \mathrm{~h}$, stained in ethidium bromide $(0.5 \mu \mathrm{g} / \mathrm{ml})$, viewed under UV light, then photographed using Polaroid 667 film (Polaroid Corporation, UK). Negative controls, using sterile double-distilled $\mathrm{H}_{2} \mathrm{O}$ instead of DNA, were included in each experiment and amplification reactions were performed at least twice, with identical results.

ISSR-primed PCR. PCR amplification. Genetic characterization was carried out on genomic DNA obtained from 129 isolates of Colletotrichum (Table 1) and 1 isolate of Eutypa lata (M280) using inter-simple-sequence-repeat (ISSR)-primed PCR. Ten ISSR primers derived from microsatellite sequences and R1 (52) and M13 (45) primers were tested on seven Colletotrichum isolates. Primers $(\mathrm{CAG})_{5},(\mathrm{GACA})_{4},(\mathrm{GTG})_{5},(\mathrm{GACAC})_{3},(\mathrm{CAC})_{5}$, and $(\text { GGAT })_{4}$ revealed clear and polymorphic patterns and, thus, were used in further analysis. PCR amplifications were performed in a total volume of $20 \mu \mathrm{l}$, comprising $5 \mathrm{ng}$ of genomic DNA; $50 \mathrm{mM} \mathrm{KCl} ; 10 \mathrm{mM}$ Tris- $\mathrm{HCl} ; 0.2 \mathrm{mM}$ each dATP, dCTP, dGTP, and dTTP; $1.5 \mathrm{mM} \mathrm{MgCl} 2 ; 1$ unit of Taq DNA polymerase (Promega Corp.); and $1 \mu \mathrm{M}$ primer. The DNA was amplified in a thermocycler (PTC-100; MJ Research), starting with 5 min of denaturation at $95^{\circ} \mathrm{C}$ followed by 30 cycles of $30 \mathrm{~s}$ at $95^{\circ} \mathrm{C}, 30 \mathrm{~s}$ at either $60^{\circ} \mathrm{C}$ (for $(\mathrm{CAG})_{5},(\mathrm{GTG})_{5}$, and $(\mathrm{CAC})_{3}$ ) or $48^{\circ} \mathrm{C}$ (for $(\mathrm{GACA})_{5},(\mathrm{GGAT})_{4}$, and $\left.(\mathrm{GACAC})_{3}\right)$, and $90 \mathrm{~s}$ at $72^{\circ} \mathrm{C}(18)$. Amplification products were separated in agarose gels $(1.5 \% \mathrm{w} / \mathrm{v})$ in $0.5 \times$ Tris-borate EDTA buffer $(45 \mathrm{mM}$ Tris-borate, $1 \mathrm{mM}$ EDTA), electrophoresed, stained, and photographed as previously described. Negative controls, using sterile double-distilled $\mathrm{H}_{2} \mathrm{O}$ instead of DNA, were included in each experiment. Two amplifications of each isolate were performed and band patterns compared. If the duplicates were not identical, a third amplification was performed. In that case, only bands that were bright, clear, and reproducible across the three repetitions were used for analysis. PCR products with a molecular weight of $\approx 180$ to $1,300 \mathrm{bp}$ were included in the analysis.

Analysis of ISSR-primed PCR. For ISSR-primed PCR, bands were scored as present $(=1)$ or absent $(=0)$ and a binary data matrix generated. Similarity among isolates was determined using the simple matching coefficient. The resulting similarity matrix was clustered by unweighted pair group method with arithmetic means (UPGMA), generating a phenogram using NTSYSpc (version 2.02k; Exeter Software, Setuaket, NY). A cophenetic coefficient was calculated (29) to determine the goodness of fit of the cluster analysis to the data. Values of $\geq 0.9$ indicate that clusters within the data are highly likely to be real, indicating that the clusters are a very good fit to the data (38). The bootstrap technique of Felsenstein (15) using Treecon for Windows (version 1.3b) (50) was also used to support the phenogram branches.

ITS1-2 sequence analysis. Sequencing procedure. Isolates of Colletotrichum spp. chosen for sequence analysis were representatives from each of the main almond-growing regions in Australia available at the time as well as reference isolates from Israel and California. PCR-amplified ribosomal DNA products from representative isolates using the primer pair ITS1 and ITS4 (53) resulted in a product of $\approx 560 \mathrm{bp}$, which was extracted from agarose gels using the Jetsorb kit (Genomed GmbH, Germany). The Big Dye Terminator DNA sequencing kit (Perkin-Elmer Inc., Branchburg, NJ) was used for determining sequence of the ITS12 regions (53). The sequence was determined using an $\mathrm{ABI}$ prism 377 DNA sequencer (Applied Biosystem Inc., Foster City, CA) and was performed by the Molecular Biology Center, Ness Ziona, Israel.

ITS sequence analysis. Analysis of ITS sequences was carried out using the ARB program package (28) and MEGA version 4 (49). Alignment of sequences was performed with the ARB automated alignment tool and alignments were refined manually. Analyses were performed by applying ARB parsimony, distance matrix, and maximum-likelihood methods. Neighbor joining with bootstrap analysis was performed (1,000 replicates; seed = 64,238 ) using MEGA version 4. Analysis was conducted on the ITS1-2 (370 sites) sequences of DNA from eight representative isolates of Colletotrichum from almond: seven from Australia (S43, CSL-1318, CSL-1688, CSL-1689, CSL-1690, W16, and W153) and one from the United States (US-1813). Complete ITS 1-2 sequences of the isolates were submitted to GenBank, with accession numbers appearing in Figure 1. Additional Colletotrichum sequences retrieved from the GenBank are included in this study for comparison (Fig. 1).

Mycelial growth rate. A 5-mm plug was excised from the margin of 7-day-old colonies of 15 isolates grown on PDA. The mycelial plug was placed in the center of a $90-\mathrm{mm}$ petri dish containing PDA and incubated in the dark at 4, 10, 15, 20, 25, 30, or $35^{\circ} \mathrm{C}$ for 7 days. Colony diameter was measured from day three until day seven and the mean radial growth rate $(\mathrm{mm} /$ day) determined for each isolate at each temperature. The experiment was a split-plot design, with three replicates of each isolate at each temperature, and was conducted twice. The data were analyzed by two-way analysis of variance (ANOVA) and, because there was no significant difference between the two sets, the data were combined. The growth rate of each isolate was then calculated using the slope of simple linear regression. Subsequently, one-way ANOVA was performed on the growth rate of isolates at each temperature and the means were separated using Tukey's test at the 5\% level. All analyses were carried out using Genstat for Windows, 6th edition.

Pathogenicity tests. Pathogenicity tests were carried out on detached leaves and fruit from cvs. Price and Nonpareil. In all, 13 isolates, 12 from various almond-growing regions of Australia and 1 from Israel (ALM-KSH-10), were tested in 2002 and 10 isolates from almond in Australia, 1 from Israel, and 2 from California, representative of the gray (US-1776) and pink (US-1796) subpopulations, were tested in 2003. Leaves and fruit were collected in September, $\approx 6$ weeks post petal fall, in 2002 and in October, $\approx 10$ weeks post petal fall, in 2003. All plant material was collected from trees that were $\approx 10$ years old in an orchard at Waikerie, SA.

Plant material was surface sterilized and inoculated with $5 \mu \mathrm{l}$ of spore suspension $\left(1 \times 10^{6}\right.$ conidia/ml $)$, then wounded by passing a needle through the inoculum droplet to pierce the epidermis. Detached leaves were placed on toothpicks on the surface of $0.5 \%$ tap water agar in petri dishes. Detached fruit were placed onto individual wire mesh racks contained in plastic trays lined with two layers of cloth (Chux) and two layers of paper towel moistened with SDW, and enclosed in a plastic bag. The fruit were sprayed with a fine mist of SDW 3 days after inoculation (8). Controls were mock inoculated with droplets of SDW. Plant material was incubated in the dark at $25^{\circ} \mathrm{C}$ for 7 days, the number of lesions counted, and lesion diameter measured.

The experiments were conducted as a completely randomized block design with six replicates in 2002 and repeated as fully as practicable in 2003 with eight replicates. To test the interaction between isolate and cultivar, data were subjected to two-way ANOVA and Fisher's least significant difference was used to separate treatment means (Genstat for Windows, 6th edition). 


\section{RESULTS}

Isolation of $\boldsymbol{C}$. acutatum from almond. C. acutatum was recovered from peduncles, leaves, and mummified fruit collected from orchards in Willunga, Angle Vale, and Munno Para Downs, SA. None was obtained from any other region surveyed in 2001. Isolates from other growing regions had been established prior to the survey or were provided by other researchers.

Taxon-specific PCR. All the isolates of Colletotrichum obtained from almond in Australia, California, and Israel, including the reference isolates of $C$. acutatum from Australia and California, produced a 490-bp fragment following PCR with primers CaInt2 and ITS4 (data not shown). Likewise, isolates from olive, pistachio, wine grape, strawberry, blueberry, and avocado, identified as $C$. acutatum based on morphology, produced an amplicon of $490 \mathrm{bp}$. No PCR product was obtained from isolates of C. gloeosporioides (S54, Or1, AVO-58, and AVO-37-4B) or of fungi other than Colletotrichum spp. C. gloeosporioides reference isolates (AVO-58 and AVO-37-4B) and isolates of putative $C$. gloeosporioides (S54 and Or1) produced a fragment of $450 \mathrm{bp}$ following PCR with the primers $C g$ Int and ITS4, whereas none of the isolates of $C$. acutatum or other fungi produced an amplicon under these reaction conditions (data not shown).

Morphological characterization. There was considerable variation among the 118 isolates of Colletotrichum spp. examined. Based on general colony appearance, four main groups

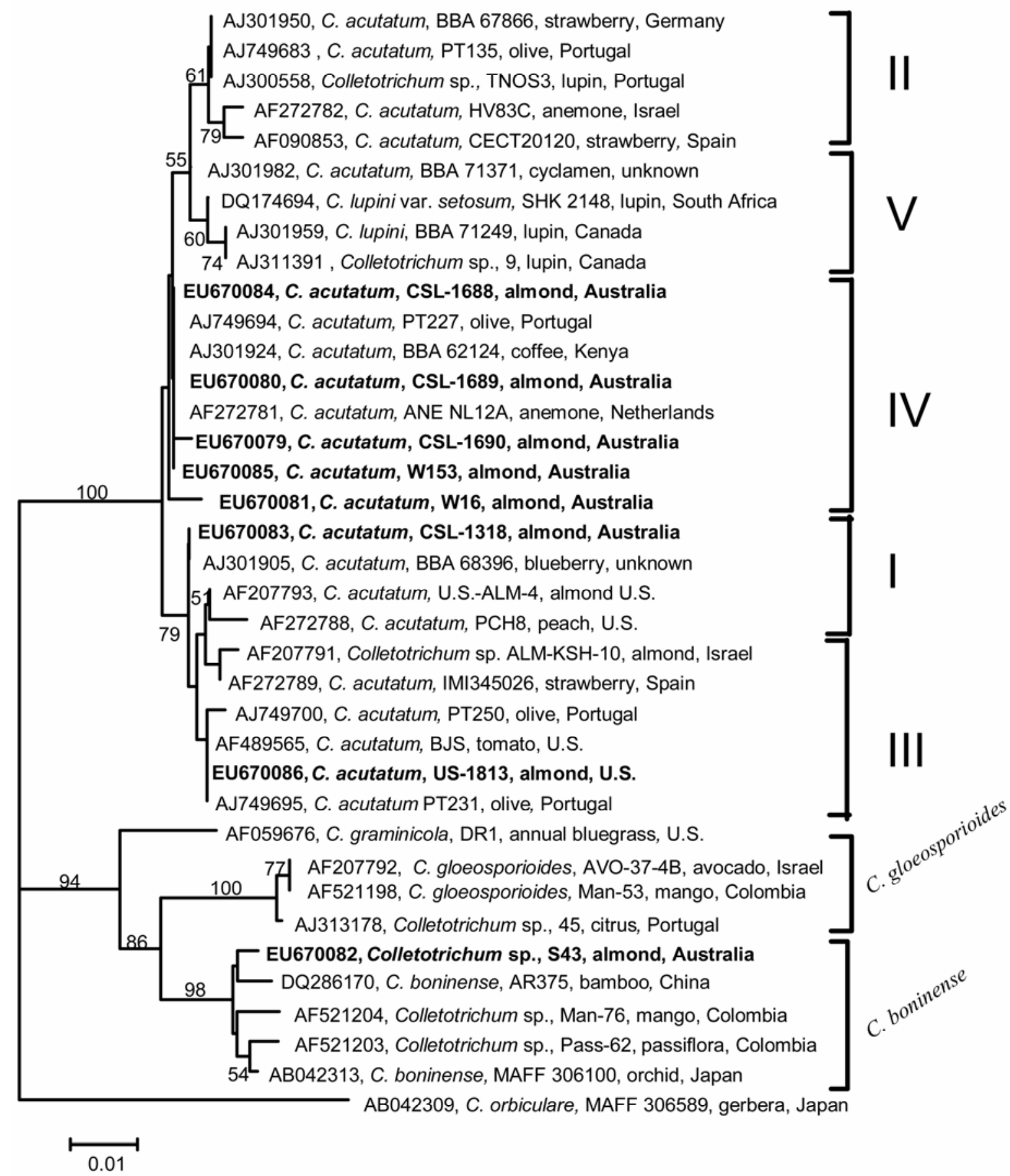

Fig. 1. Tree comparing relationships among Colletotrichum isolates and published sequences following internal transcribed spacer 1-2 sequence analysis. Bootstrapped neighbor-joining trees were generated with 1,000 resamplings, and nodes with bootstrap values of $>50 \%$ are indicated. The order of branching was similar in all tree construction approaches used (see Materials and Methods). Scale bar indicates estimated $1 \%$ sequence divergence. Isolates in bold are those sequenced in this study. Roman numerals I to IV refer to four clades of Colletotrichum acutatum based on sequence analysis. 
could be distinguished: pink, orange, cream, and gray. The pink group contained the majority of isolates of $C$. acutatum from almond in Australia and most of those from the pink subpopulation in California. The color of the Australian isolates ranged from bright pink to carmine, whereas the Californian isolates were light pink to orangey pink. The orange group contained six isolates from almond in Australia. The cream group contained 10 isolates of $C$. acutatum from almond in Australia and 1 isolate from California (ALM-US-12). The gray group consisted of isolates of Colletotrichum from almond in Israel and from the gray subpopulation of $C$. acutatum from almond in California as well as isolates of $C$. gloeosporioides from avocado in Israel and from orange in Australia.

The isolates from almond in Australia and from the pink subpopulation in California sporulated profusely, whereas those from the gray subpopulation in California, almond in Israel, and the cream group produced few conidia. There was considerable variation in conidial length and width among Australian isolates of $C$. acutatum from almond (Table 2). The majority of conidia from Australian almond isolates were elliptical. However, many conidia were fusiform, some were cylindrical, and several intermediate forms occurred also. Intermediate forms occurred also for the Californian and Israeli isolates; however, fusiform conidia were predominant for the isolates of the pink subpopulation from California, whereas conidia from isolate US-1813, representative of the gray subpopulation from California, were generally elliptical. In general, the conidia of Israeli isolates from almond were intermediate between elliptical and cylindrical. Overall, there were no obvious differences among the pink, orange, or cream groups of Australian isolates with respect to conidial morphology. Conidial size and shape did not assist in differentiation of groups among Australian isolates or among isolates from each country. Conidia from isolates of C. gloeosporioides from orange in Australia and from avocado in Israel were, in general, longer and wider and had more rounded ends than conidia of $C$. acutatum from almond.

ISSR-PCR analysis. A total of 71 clear and reproducible bands was produced following PCR with the six selected ISSR primers. Banding patterns from representative isolates following PCR amplification with primer $(\mathrm{GTG})_{5}$ are shown in Figure 2. The primers amplified 18 to 31 bands for all isolates, without monomorphic bands. Cluster analysis, using UPGMA, revealed several groups which were strongly supported by bootstrap analysis, and the cophenetic coefficient was 0.99 (Fig. 3). There were four groups of Colletotrichum spp. from almond, each containing isolates that shared $100 \%$ similarity, designated groups one to four. Group one contained all of the isolates from almond in Australia, except for CSL-1318. Isolate CSL-1318 was most similar to an isolate from avocado in Australia, CSL-1298. Group one also included isolate P1 from pistachio and three from olive in Australia (Se37, OL3, and OL4). Group two comprised all isolates from the pink subpopulation from almond in California. Group three contained isolates from almond in Israel and group four contained both isolates from the Californian gray sub- population of $C$. acutatum. The two isolates of $C$. gloeosporioides from orange in Australia were identical.

Isolates of $C$. acutatum from several plants other than almond, including strawberry, olive, wine grape, and blueberry in Australia, formed a cluster and were most similar to $C$. acutatum isolates from almond in Australia (group one). Isolates of $C$. gloeosporioides from avocado from Israel (AVO-58 and AVO-374B) were similar to each other and to an isolate of $C$. acutatum from strawberry (TUT-5954) from Israel. These three isolates from Israel were the least similar to all of the other Colletotrichum isolates tested in this study.
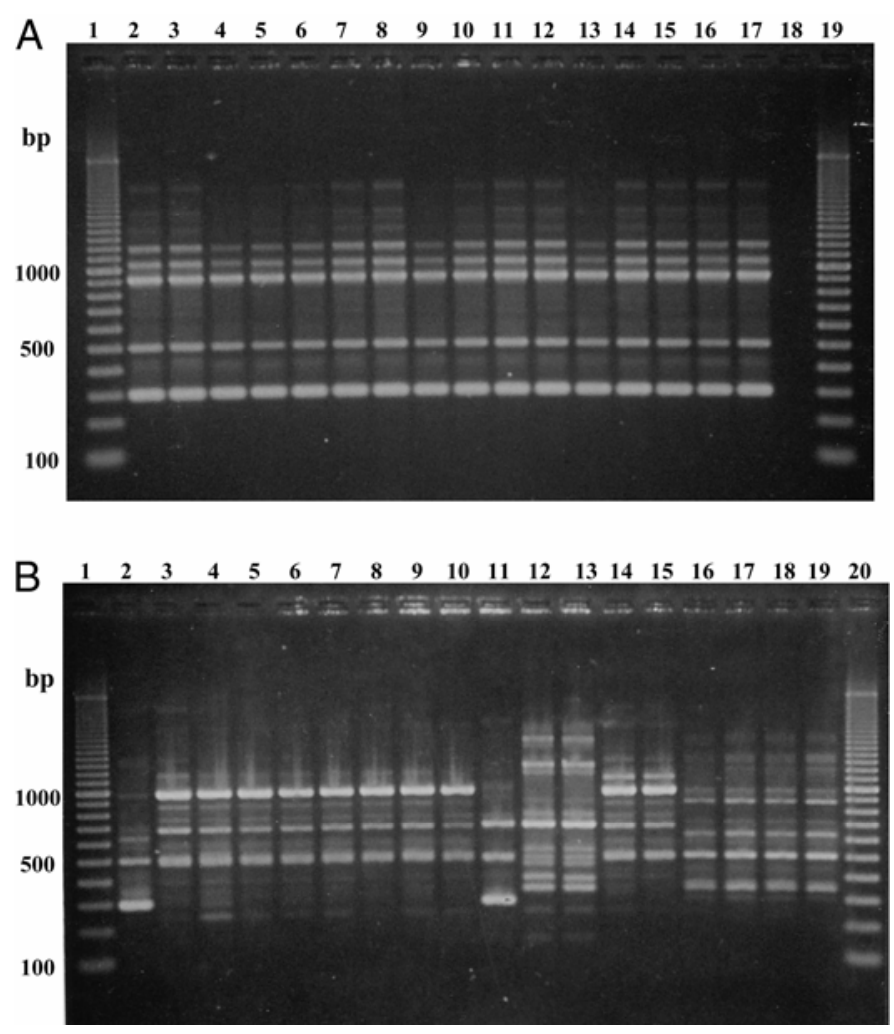

Fig. 2. DNA banding patterns of 34 isolates of Colletotrichum spp. obtained following polymerase chain reaction with the inter-simple sequence repeat primer (GTG) 5 . A, Lanes 1 and 19, 100-bp ladder; lanes 2 to 17, Colletotrichum acutatum from almond in Australia (CSL-1690, W1, W2, W4p, W4m, W5m, W5p, W5L, W6m, W7p, W8, W16, W17, W26, and W29); lane 18, double-distilled $\mathrm{H}_{2} \mathrm{O}$. B, Lanes 1 and 20, 100-bp ladder; lane 2, C. acutatum from avocado in Australia (CSL-1298); lanes 3 to 10, Colletotrichum sp. from almond in Israel (ALM-NRB-3DK, ALM-BZR-8L, ALM-KSH-10, ALMGZT-1F, ALM-GOZ-42B, ALM-GOZ-42B, and ALM-NA-7Q); lane 11, C. acutatum from strawberry in Israel (TUT-5954); lanes 12 and 13, $C$. gloeosporioides from avocado in Israel (AVO-58 and AVO-37-4B); lanes 14 to 19, C. acutatum from almond in California (US-1776 and US-1813, representative of the gray subpopulation, and ALM-US-3, ALM-US-4, ALMUS-6B, and ALM-US-9, representative of the pink subpopulation).

TABLE 2. Conidial size for isolates of Colletotrichum spp. from almond in Australia, California, and Israel ${ }^{\mathrm{a}}$

\begin{tabular}{|c|c|c|c|c|c|c|}
\hline \multirow[b]{2}{*}{ Country, species (no. of isolates) } & \multicolumn{3}{|c|}{ Conidial length $(\mu \mathrm{m})$} & \multicolumn{3}{|c|}{ Conidial width $(\mu \mathrm{m})$} \\
\hline & Min & $\operatorname{Max}$ & Mean (SE) & Min & Max & Mean (SE) \\
\hline Australia, Colletotrichum acutatum (99) & 5.3 & 16.9 & $8.7(0.17)$ & 2.12 & 4.24 & $3.18(\leq 0.005)$ \\
\hline Pink isolates (84) & 4.24 & 14.84 & $9.0(0.01)$ & 2.12 & 4.24 & $3.0(\leq 0.005)$ \\
\hline Orange isolates (6) & 5.3 & 16.96 & $8.6(0.1)$ & 3.18 & 4.24 & $3.2(\leq 0.005)$ \\
\hline Cream isolates (9) & 5.3 & 21.2 & $9.2(0.1)$ & 3.18 & 4.24 & $3.2(\leq 0.005)$ \\
\hline \multicolumn{7}{|l|}{ California, C. acutatum } \\
\hline Pink subpopulation (8) & 6.36 & 14.84 & $9.39(0.1)$ & 2.12 & 4.24 & $3.37(0.02)$ \\
\hline Gray subpopulation (1) & 7.42 & 16.96 & $10.77(0.32)$ & 3.18 & 3.18 & $3.18(0)$ \\
\hline Israel, Colletotrichum sp. (6) & 7.42 & 19.08 & $12.42(0.1)$ & 3.18 & 4.24 & $3.29(\leq 0.005)$ \\
\hline
\end{tabular}

a Conidia harvested from colonies grown on potato dextrose agar for 14 days at $25^{\circ} \mathrm{C}$ in darkness. Min $=$ minimum, Max $=$ maximum, $\mathrm{SE}=$ standard error. 


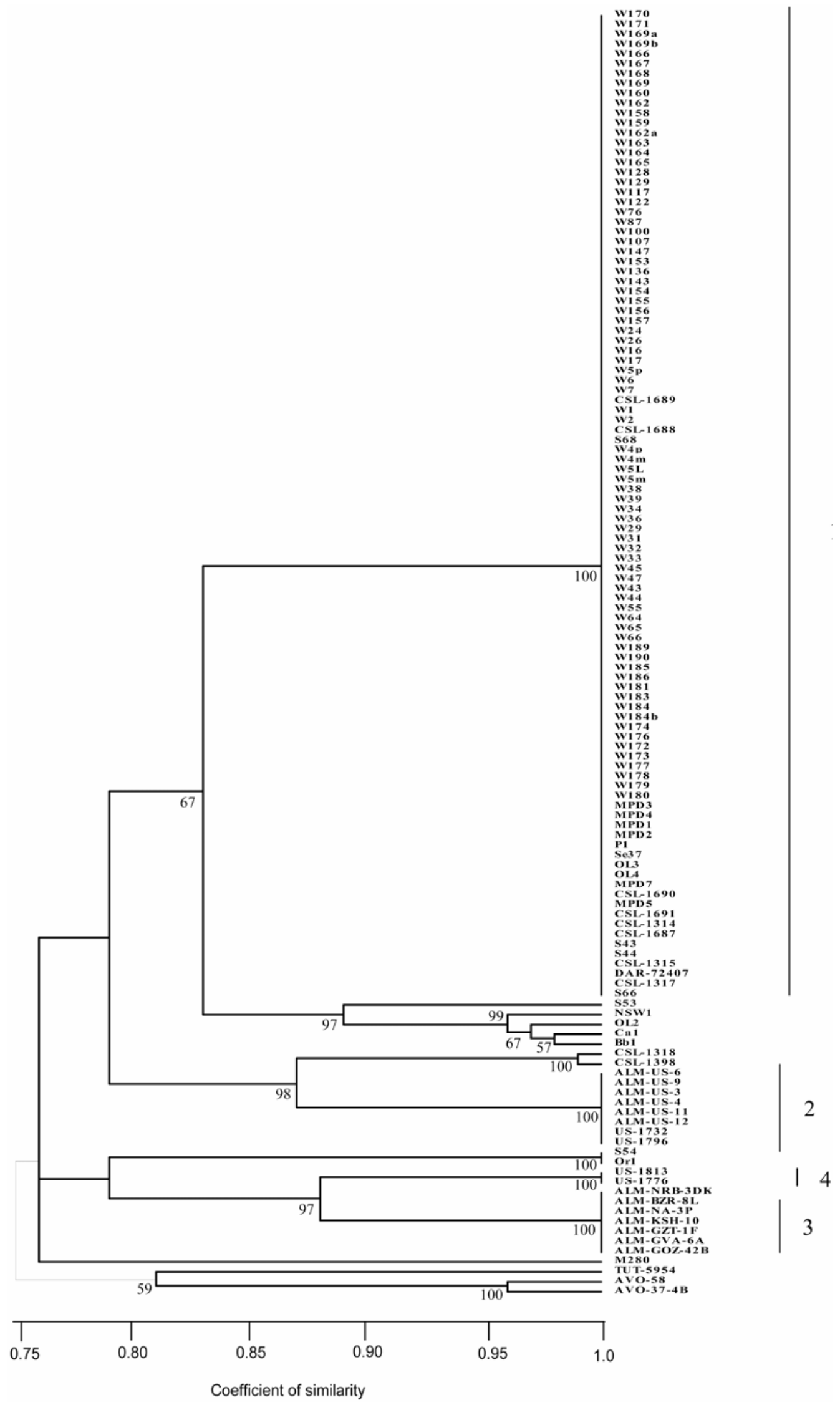

Fig. 3. Genetic similarity among isolates of Colletotrichum spp. from almond in Australia, California, and Israel; and from avocado (AVO-58, AVO-37-4B, and CSL-1298), strawberry (TUT-5954 and S53), orange (S54 and Or1), wine grape (DAR-75574), blueberry (Bb1), olive (NSW 1, Se37, OL2, OL3, and OL4), and pistachio (P1) following polymerase chain reaction with inter-simple-sequence repeat primers. An isolate of Eutypa lata (M280) from grapevine was used as an outgroup. Similarity was determined using the simple matching coefficient and unweighted pair group method with arithmetic means cluster analysis. Bootstrap values $>50 \%$ are shown. Four groups in which isolates were identical to one another are numbered 1 to 4 . 
ITS1-2 sequence analysis. Of the seven Australian $C$. $a c u$ tatum isolates analyzed, four were identical according to ITS1-2 sequence analysis and clustered within clade IV of $C$. acutatum, which also contained isolates of $C$. acutatum from anemone, olive, and coffee (Fig. 1). Although the sequence for Australian almond isolate W16 was not identical to the four Australian almond isolates in clade IV, W16 was most similar to those isolates and clustered in clade IV. Sequence data confirmed that isolate CSL-1318 was different from the other Australian isolates of $C$. acutatum and was identical in sequence to a $C$. acutatum isolate from blueberry. These two isolates grouped in clade I, which contained isolates of $C$. acutatum from almond and peach from the United States. However, isolate S43, identified as $C$. acutatum using species-specific primers and yielding banding patterns identical to those of Australian isolates of $C$. acutatum (excluding CSL-1318) using ISSR-primed PCR, was grouped within an outgroup containing isolates of $\mathrm{C}$. boninense and $\mathrm{Col}$ letotrichum spp., according to ITS1-2 sequence analysis (Fig. 1).

Mycelial growth rate. Isolates of $C$. acutatum from almond in Australia grew fastest at $25^{\circ} \mathrm{C}$ (Fig. 4A), except isolate CSL1318 , for which the mycelial growth rate at $20^{\circ} \mathrm{C}$ was the same as at $25^{\circ} \mathrm{C}$. Likewise, the maximum mycelial growth rate for isolates representative of the Californian pink and gray subpopulations of C. acutatum occurred at $25^{\circ} \mathrm{C}$, whereas isolate ALM-KSH-10, representative of Israeli Colletotrichum spp. from almond, grew more rapidly at 20 and $25^{\circ} \mathrm{C}$ than at other temperatures. Isolates
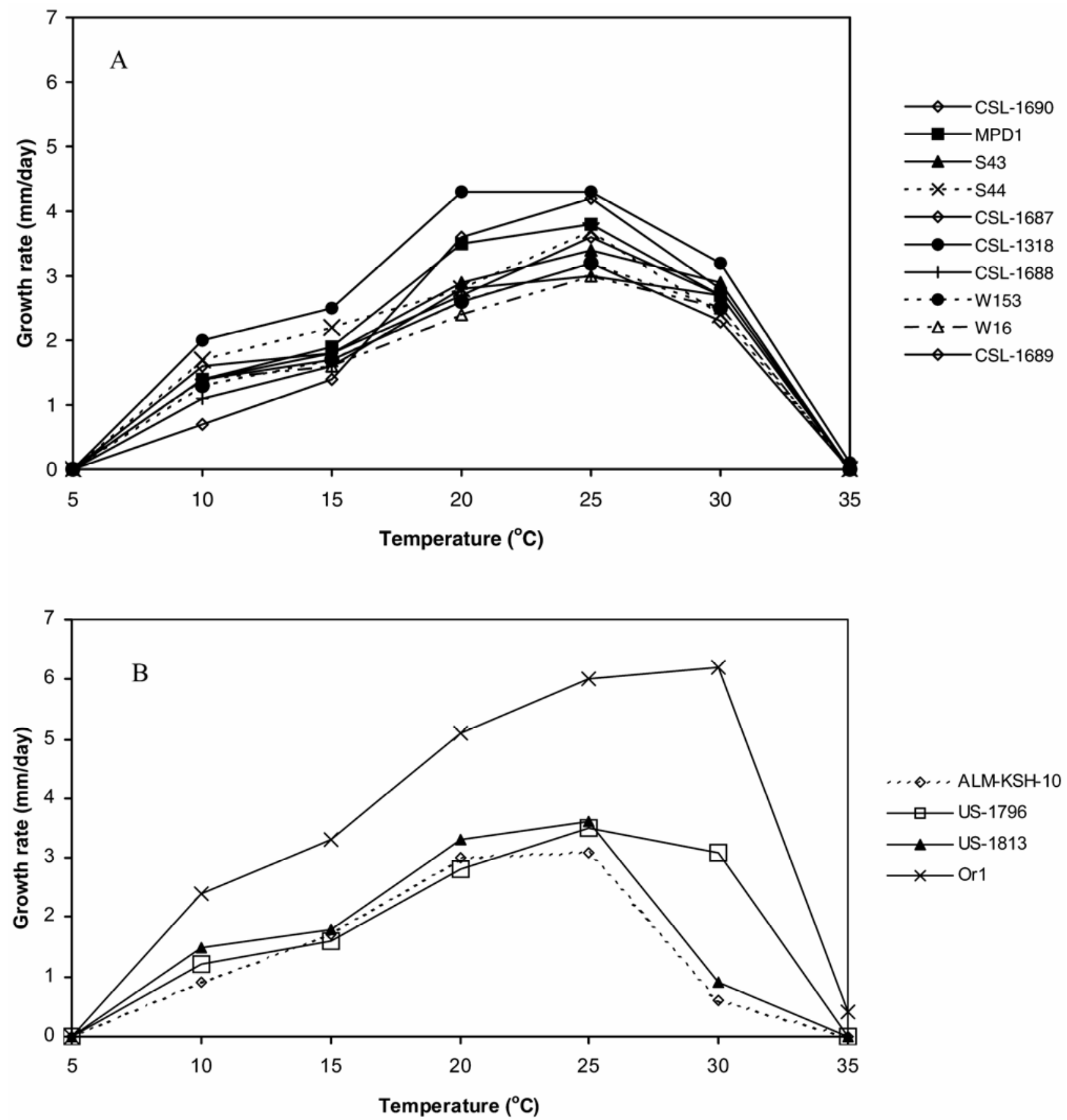

Fig. 4. Mean mycelial growth rate (mm/day) of representative isolates of Colletotrichum spp. following incubation for 7 days in the dark at 5 to $35^{\circ} \mathrm{C}$. A, Colletotrichum acutatum from almond in Australia; B, C. acutatum from almond from California (US-1796 and US-1813), Colletotrichum sp. (ALM-KSH-10) from almond from Israel, and C. gloeosporioides (Or1) from orange from Australia. Tukey's significant differences at the $5 \%$ level are as follows: 0.7 at $10^{\circ} \mathrm{C}, 0.9$ at $15^{\circ} \mathrm{C}, 1.4$ at $20^{\circ} \mathrm{C}, 1.1$ at $25^{\circ} \mathrm{C}, 0.9$ at $30^{\circ} \mathrm{C}$, and 0.2 at $35^{\circ} \mathrm{C}$. 
of C. gloeosporioides from orange in Australia grew faster than Australian almond isolates at 10 to $35^{\circ} \mathrm{C}$ (Fig. 4B).

The one-way ANOVA revealed significant variation $(P<0.001)$ in mycelial growth rate among Australian isolates of $C$. acutatum at $10,15,20,25,30$, and $35^{\circ} \mathrm{C}$. At $25^{\circ} \mathrm{C}$, the mycelial growth rates for US-1796, US-1813, and ALM-KSH-10 were not significantly different from that of $C$. acutatum from almond in Australia. At $30^{\circ} \mathrm{C}$, the Australian isolates and the pink Californian isolate grew significantly faster $(P<0.001)$ than the Israeli isolate from almond and the Californian gray isolate (Fig. 4B). The only isolates to grow at $35^{\circ} \mathrm{C}$ were C. gloeosporioides from orange in Australia (Or1 and S54) and CSL-1318, C. acutatum from almond in Australia.

Pathogenicity testing. All the isolates resulted in leaf and fruit lesions on both Price and Nonpareil and the corresponding Colletotrichum strains were reisolated from these lesions. Lesions were not evident on controls mock inoculated with SDW.

There was a significant difference among isolates for lesion diameter $(P<0.001)$ on detached leaves in 2002 and 2003 (data not shown). However, there was no consistent trend for a single isolate or group of Australian isolates to be more pathogenic than any other, whereas the Israeli isolate, ALM-KSH-10, caused significantly smaller lesions than most Australian isolates in both experiments.

There was a significant interaction $(P<0.001)$ between isolate and cultivar on detached fruit in 2002 (Fig. 5). Inoculation with isolate CSL-1689 resulted in the smallest lesions on Nonpareil and the largest on Price. Several isolates produced lesions of a similar size on both Price and Nonpareil (e.g., CSL-1687, CSL1690, and ALM-KSH-10); however, in general, lesions tended to be larger on Price than on Nonpareil. In contrast, in 2003, there was a significant difference between cultivars $(P<0.001)$ and among isolates $(P<0.001)$ (Fig. 6$)$ but no significant interaction. US-1776 caused relatively small lesions whereas US-1796 and S43 caused the largest. Lesions were smaller on Nonpareil than on Price (Fig. 6B).

\section{DISCUSSION}

Although there was morphological variation among isolates of C. acutatum from almond in Australia, they fit well within the range of descriptors used for $C$. acutatum $(13,21,41,46)$. All Australian almond isolates, as well as those from California and Israel, were confirmed as C. acutatum using taxon-specific PCR. However, according to ITS1-2 sequence data, isolate S43 grouped with the C. boninense cluster (Fig. 1).

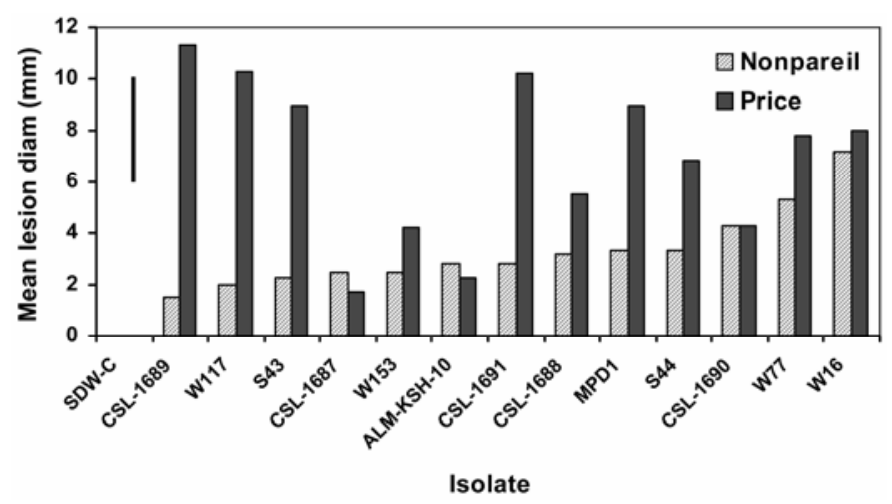

Fig. 5. Mean lesion diameter $(\mathrm{mm})$ on detached fruit of almond cvs. Price and Nonpareil 14 days after inoculation with representative isolates of Colletotrichum acutatum from almond obtained in Australia (CSL-1687, CSL-1688, CSL-1689, CSL-1690, CSL-1691, S43, S44, W16, W77, W117, W153, and MPD1) and Israel (ALM-KSH-10) in 2002. Data are means of six replicates and sterile distilled water $(\mathrm{SDW})=$ control. Error bar represents least significant difference of 4.0 .
Based on colony color, three main subgroups were evident among Australian almond isolates: pink, orange, and cream. The majority of isolates of $C$. acutatum from almond in Australia were characterized by bright pink mycelium, maximum mycelial growth rate at $25^{\circ} \mathrm{C}$, and conidia rounded at one end and pointed at the other. The range of conidium length (4.24 to $21.2 \mu \mathrm{m})$ was larger than reported for $C$. acutatum $(16,42)(8$ to $16 \mu \mathrm{m})$; however, Gunnell and Gubler (21) reported that conidia of $C$. acutatum from strawberry were longer than $16 \mu \mathrm{m}$.

Several isolates were bright orange with fusiform conidia, a shape generally considered typical of $C$. acutatum (21,41). C. acutatum with orange colonies on PDA have been obtained from grape, blueberry, (54) strawberry (11), and ugurassa (24) but not previously from almond. Cream or white colonies, uncommon in this study, have also been described $(13,21,41)$.

Australian isolates of $C$. acutatum from almond most closely resembled representatives of the Californian pink subpopulation in terms of colony color, conidial shape and size, and mycelial growth rate.

The collection of Colletotrichum isolates examined here could not be assigned to species or subspecific groups on the basis of colony morphology and conidial size or shape. Culture medium and environmental conditions are known to affect morphology, including conidial shape $(3,21,42)$, which may confound comparisons among laboratories. However, isolates of $C$. acutatum could be distinguished from those of $C$. gloeosporioides by the slower mycelial growth and lower optimal temperature of the former. This supports previous reports $(19,25,30,46,54)$ that delineation of species and subspecies should not rely on morphology alone.

There was no apparent link between geographical area and morphological and cultural characteristics of the Australian isolates of $C$. acutatum from almond. However, most isolates
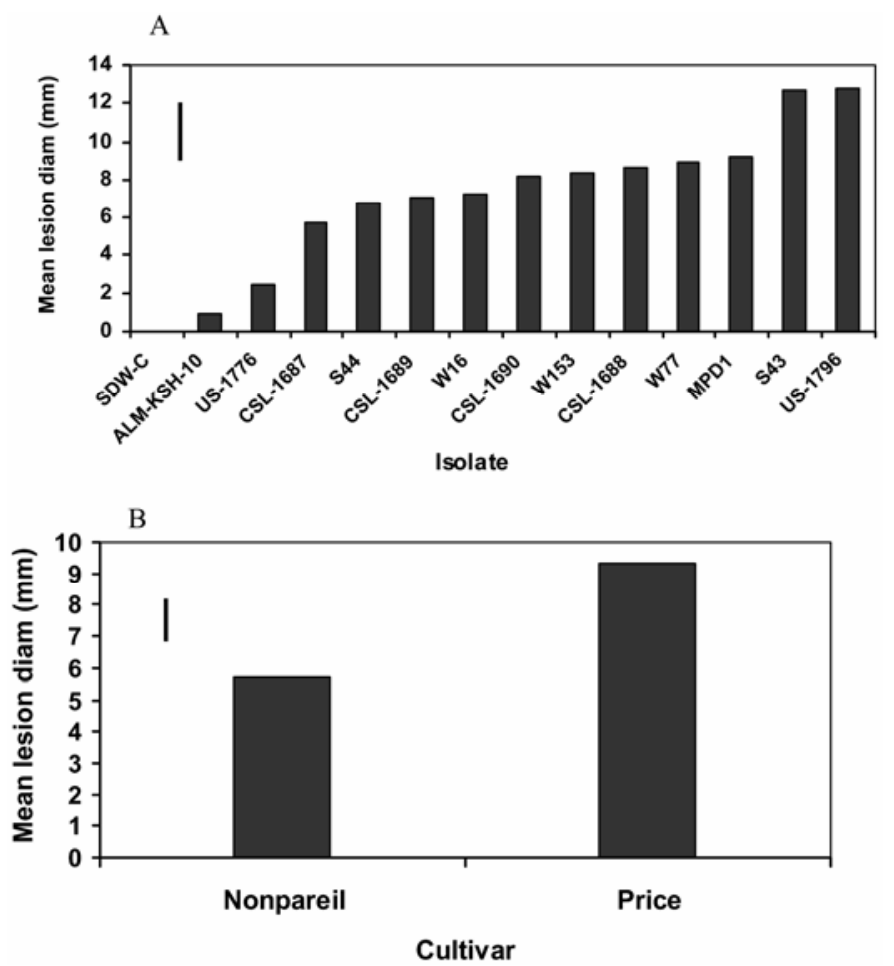

Fig. 6. Mean lesion diameter $(\mathrm{mm})$ on detached almond fruit 7 days after wounding and inoculation with representative isolates of Colletotrichum acutatum from almond in Australia (CSL-1687, CSL-1688, CSL-1689, CSL1690, S43, S44, W16, W77, W153, and MPD1), California (US-1776 and US1796), and Israel (ALM-KSH-10) in 2003. Data are means of eight replicates and sterile distilled water $(\mathrm{SDW})=$ control. $\mathbf{A}$, Price and Nonpareil cultivars combined, error bar represents least significant difference (LSD) of 3.2. B, Isolates combined for each cultivar, error bar represents LSD of 1.3. 
were obtained from Willunga and the Northern Adelaide Plains (SA) whereas some important almond-growing areas were not represented at all, such as the Riverland (SA), Lindsay Point, and Red Cliffs (Victoria) (8).

In contrast to morphology, taxon-specific and ISSR-primed PCR distinguished isolates of $C$. acutatum from those of $C$. gloeosporioides. However, ISSR-primed PCR revealed a uniform banding pattern among Australian isolates of C. acutatum from almond, except for CSL-1318. The predominant ISSR-PCR phenotype was also displayed by two isolates from olive and one from pistachio, indicating that this phenotype was not unique to almond. Isolate CSL-1318 was most similar to an isolate from avocado in SA and, in terms of a banding patterns, both shared $87 \%$ similarity with the Californian pink subgroup. Isolate CSL1318 was more similar to the Californian pink subgroup than to the main group of Australian C. acutatum isolates from almond.

Based on ISSR-PCR, all isolates from almond in Australia produced banding patterns different from those in California and Israel. The pink and gray Californian subpopulations of $C$. acutatum differed from one another yet were homogeneous within subpopulations, which is consistent with the findings of Förster and Adaskaveg (16) and Freeman et al. (18). Isolates from the pink and gray Californian subpopulations differed from the Israeli isolates of Colletotrichum from almond, which confirmed a previous comparison of Israeli isolates and pink Californian isolates by Freeman et al. (18). In contrast, Förster and Adaskaveg (16) reported the gray isolates from almond in California to have banding patterns "almost identical" to those of the isolates from Israel based on random amplified polymorphic DNA PCR.

The ITS1-2 sequence analysis concurred with results of ISSRPCR in that Australian isolates from almond were not unique when compared with isolates from other hosts.

Five of the representative Australian isolates were grouped in clade IV, one was within clade I, and one (S43) was within the $C$. boninense clade. Based on morphology, isolate $\mathrm{S} 43$ is consistent with $C$. acutatum; however, the placement of isolate $\mathrm{S} 43$ requires further investigation. Also in clade I was the pink U.S. almond isolate ALM-US-4 whereas the gray representatives from almond from the United States (US-1813) and Israel (ALM-KSH-10) delineated to clade III. According the ITS1-2 sequences, therefore, isolates of $C$. acutatum from almond in Australia, Israel, and the United States belong to at least three distinct groups, two of which are represented in Australia. Clades I and IV correspond to groups A3 and A5 of the eight molecular groups of C. acutatum identified among a worldwide collection from various hosts by Sreenivasaprasad and Talhinhas (44). Group A5 isolates, which are predominantly carmine in color, are reported to be common in Australia, New Zealand, and South Africa (44). That the majority of the representative Australian almond isolates subjected to ITS1-2 sequence analysis belonged to clade IV supports that study. Likewise, the Australian almond isolate (DAR72407) examined by Whitelaw-Weckert et al. (54) belonged to clade IV.

Although all isolates of Colletotrichum from almond in Australia, California, and Israel were pathogenic to detached leaves and fruit of both Price and Nonpareil in vitro, no single isolate or group of Australian isolates was consistently more pathogenic than any other. In contrast, consistent variation has been reported among isolates of $C$. acutatum from strawberry in Europe $(10,11)$, between the two Californian subpopulations of $C$. acutatum from almond (16), and among isolates of $C$. gloeosporioides from avocado in Israel (17). Although in vitro pathogenicity tests suggested little difference in the susceptibility of Price and Nonpareil, smaller lesions on fruit of Nonpareil than Price in 2003 supported previous reports that Nonpareil is less susceptible than other cultivars $(2,12,31)$. Pathogenicity testing of a range of isolates to other almond cultivars may reveal additional variation and elucidate differences in susceptibility. Furthermore, pathogenicity of C. acutatum isolates from other host plants to almond should be tested.

An isolate of C. gloeosporioides from orange in Australia caused lesions on almond fruit in vitro, which suggested that $C$. gloeosporioides may have the potential to infect almond in the field. Orange and almond are cultivated in close proximity in some regions of Australia and, if anthracnose caused by $C$. gloeosporioides was to occur on orange and spread to almond orchards nearby, C. gloeosporioides could pose a threat to the almond industry.

The finding that groups based on morphology and pathogenicity were not supported by ISSR-primed PCR agrees with studies by Ansari et al. (5) of C. lindemuthianum from bean and Sanders and Korsten (39) of $C$. gloeosporioides from mango and avocado. In contrast, Abang et al. (1) found that two morphotypes of C. gloeosporioides from yam were distinguishable based on colony and conidial morphology, growth rate, virulence, and vegetative compatibility group (VCG) analysis as well as ISSRprimed PCR and denaturing gradient-gel electrophoresis.

Based on ISSR-PCR fingerprints and ITS1-2 sequence data, the majority of Australian isolates did not display a unique phenotype because they shared homology with isolates from other hosts obtained from within Australia and other countries. More isolates from a range of host plants should be characterized, including the use of VCG analysis, and compared with isolates from almond to improve understanding of the relationships among isolates of $C$. acutatum from this host and the relationship to Colletotrichum spp. infecting other hosts.

\section{ACKNOWLEDGMENTS}

This research was supported by an Australian postgraduate scholarship, a University of Adelaide Research National award, and an Almond Board of Australia scholarship awarded to Suzanne McKay (formerly Colmagro). We thank B. Hall and N. Cunningham (South Australian Research and Development Institute, SA), J. Adaskaveg and H. Förster (University of California, Riverside), G. Ash (Charles Sturt University, NSW, Australia), A. Watson (NSW Agriculture, Australia), M. Cole (Monash University, Victoria, Australia), and R. Lardner (University of Adelaide, SA, Australia) for providing isolates; and R. Lardner for assistance with data analysis.

\section{LITERATURE CITED}

1. Abang, M. M., Fagbola, O., Smalla, K., and Winter, S. 2005. Two genetically distinct populations of Colletotrichum gloeosporioides Penz. causing anthracnose disease of Yam (Dioscorea spp.). Phytopathology 153:137-142.

2. Adaskaveg, J. E., and Förster, H. 2000. Occurrence and management of anthracnose epidemics caused by Colletotrichum species on tree fruit crops in California. Pages 317-336 in: Colletotrichum: Host Specificity, Pathology and Host-Pathogen Interaction. D. Prusky, S. Freeman, and M. B. Dickman, eds. The American Phytopathological Society, St. Paul, MN.

3. Adaskaveg, J. E., and Hartin, R. J. 1997. Characterization of Colletotrichum acutatum isolates causing anthracnose of almond and peach in California. Phytopathology 87:979-987.

4. Afanador-Kafuri, L., Minz, D., Maymon, M., and Freeman, S. 2003 Characterization of Colletotrichum isolates from tamarillo, passiflora, and mango in Colombia and identification of a unique species from the genus. Phytopathology 93:579-587.

5. Ansari, K. I., Palacios, N., Araya, C., Langin, T., Egan, D., and Doohan, F. M. 2004. Pathogenic and genetic variability among Colletotrichum lindemuthianum isolates of different geographic origins. Plant Pathol. 53:635-642.

6. Brizi, U. 1896. Eine neue krankheit (Anthracosis) des mandelbaumes. Z. Pflanzenkrankh. Gallenkd. 6:63-72.

7. Cannon, P. F. 1998. International Course on the Identification of Fungi of Agricultural and Environmental Significance. Colletotrichum. CABI Bioscience, UK.

8. Colmagro, S. F. 2005. Anthracnose on almond: epidemiology and characterization of Colletotrichum acutatum. Ph.D. thesis, The University of Adelaide, South Australia, Australia. 
9. Czarnecki, H. L. 1916. A Gloeosporium disease of the almond probably new to America. (Abstr.) Phytopathology 6:310.

10. Denoyes, B., and Baudry, A. 1995. Species identification and pathogenicity study of French Colletotrichum strains isolated from strawberry using morphological and cultural characteristics. Phytopathology 85:5357.

11. Denoyes-Rothan, B., Guérin, G., Délye, C., Smith, B., Minz, D., Maymon, M., and Freeman, S. 2003. Genetic diversity and pathogenic variability among isolates of Colletotrichum species from strawberry. Phytopathology 93:219-228.

12. Diéguez-Uribeondo, J., Förster, H., and Adaskaveg, J. 2002. Temperature and wetness duration requirements for almond anthracnose development on leaves and blossoms. (Abstr.) Phytopathology 92:S19.

13. Dyko, B. J., and Mordue, J. E. M. 1979. Colletotrichum acutatum. Commonwealth Mycological Institute Descriptions of Pathogenic Fungi and Bacteria 630.

14. Farr, D. F., Aime, M. C., Rossman, A. Y., and Palm, M. E. 2006. Species of Colletotrichum on Agavaceae. Mycol. Res. 110:1395-1408.

15. Felsenstein, J. 1985. Confidence limits in phylogenies: an approach using the bootstrap. Evolution 39:783-791.

16. Förster, H., and Adaskaveg, J. E. 1999. Identification of subpopulations of Colletotrichum acutatum and epidemiology of almond anthracnose in California. Phytopathology 89:1056-1065.

17. Freeman, S., Katan, T., and Shabi, E. 1996. Characterization of Colletotrichum gloeosporioides isolates from avocado and almond fruits with molecular and pathogenicity tests. Appl. Environ. Microbiol. 62:10141020.

18. Freeman, S., Minz, D., Jurkevitch, E., Maymon, M., and Shabi, E. 2000. Molecular analyses of Colletotrichum species from almond and other fruits. Phytopathology 90:608-614.

19. Freeman, S., Minz, D., Maymon, M., and Zveibil, A. 2001. Genetic diversity within Colletotrichum acutatum sensu Simmonds. Phytopathology 91:586-592.

20. Guerber, J. C., Liu, B., Correll, J. C., And Johnston, P. R. 2003. Characterization of diversity in Colletotrichum acutatum sensu lato by sequence analysis of two gene introns, mtDNA and intron RFLPs, and mating compatibility. Mycologia 95:872-895.

21. Gunnell, P. S., and Gubler, W. D. 1992. Taxonomy and morphology of Colletotrichum species pathogenic to strawberry. Mycologia 84:157-165.

22. Hall, B. H., Jones, M. K., and Wicks, T. J. 1998. First report of anthracnose of almond in South Australia. Aust. Plant Pathol. 27:127.

23. Heintz, C. 1997. Board gears up to tackle anthracnose disease problem. Aust. Nut Grow. June-August:26.

24. Jayasinghe, C. K., and Fernando, T. H. P. S. 2004. Re-identification and characterization of pathogens causing ugurassa (Flacourtia inermis) fruit anthracnose. Mycopathologia 157:81-85.

25. Johnston, P. R., and Jones, D. K. 1997. Relationships among Colletotrichum isolates from fruit-rots assessed using rDNA sequences. Mycologia 89:420-430.

26. Lardner, R., Johnston, P. R., Plummer, K. M., and Pearson, M. N. 1999. Morphological and molecular analysis of Colletotrichum acutatum sensu lato. Mycol. Res. 103:275-285.

27. Lotter, H. C., and Berger, D. K. 2005. Anthracnose of lupins in South Africa is caused by Colletotrichum lupini var. setosum. Aust. Plant Pathol. 34:385-392.

28. Ludwig, W., Strunk, O., Westram, R., Richter, L., Meier, H., Yadhukumar, Buchner, A., Lai, T., Steppi, S., Jobb, G., Forster, W., Brettske, I., Gerber, S., Ginhart, A. W., Gross, O., Grumann, S., Hermann, S., Jost, R., Konig, A., Liss, T., Lussmann, R., May, M., Nonhoff, B., Reichel, B., Strehlow, R., Stamatakis, A., Stuckmann, N., Vilbig, A., Lenke, M., Ludwig, T., Bode, A., and Schleifer, K.-H. 2004. ARB: a software environment for sequence data. Nucleic Acids Res. 32:1363-1371.

29. Mantel, N. A. 1967. The detection of disease clustering and a generalized regression approach. Cancer Res. 27:209-220.

30. Martin, M. P., and García-Figueres, F. 1999. Colletotrichum acutatum and C. gloeosporioides cause anthracnose on olives. Eur. J. Plant Pathol. 105:733-741.

31. McMichael, P. A. 2000. The Control and Management of 'Anthracnose' of Almonds. Scholefield Robinson Horticultural Services Pty. Ltd., Netherby, South Australia, Australia.

32. Mills, P. R., Sreenivasaprasad, S., and Brown, A. E. 1994. Detection of the anthracnose pathogen Colletotrichum. Pages 183-190 in: Modern Assays for Plant Pathogenic Fungi: Identification, Detection and Quantification. A. Shots, R. Oliver, and F. M. Dewey, eds. CAB International, Oxon, UK.

33. Moriwaki, J., Sato, T., and Tsukiboshi, T. 2003. Morphological and molecular characterization of Colletotrichum boninense sp. nov. from Japan. Mycoscience 44:47-53.

34. Moriwaki, J., Tsukiboshi, T., and Sato, T. 2002. Grouping of Colletotrichum species in Japan based on rDNA sequences. J. Gen. Plant Pathol. 68:307-320.

35. Nirenberg, H. I., Feiler, U., and Hagedorn, G. 2002. Description of Colletotrichum lupini comb. nov. in modern terms. Mycologia 94:307320.

36. Raynor, R. W. 1970. A Mycological Colour Chart. CAB International, Surrey, UK.

37. Rodriguez, R. J., and Yoder, O. 1991. A family of conserved repetitive DNA elements from the fungal plant pathogen Glomerella cingulata (Colletotrichum lindemuthianum). Exp. Mycol. 15:232-242.

38. Rohlf, F. J. 1997. NTSYS-pc: Numerical Taxonomy and Multivariate Analysis System. Version 2.00. Exeter Software, Setauket, NY.

39. Sanders, G. M., and Korsten, L. 2003. A comparative morphological study of South African avocado and mango isolates of Colletotrichum gloeosporioides. Can. J. Microbiol. 81:877-885.

40. Shabi, E., and Katan, T. 1983. Occurrence and control of anthracnose of almond in Israel. Plant Dis. 67:1364-1366.

41. Simmonds, J. H. 1965. A study of the species of Colletotrichum causing ripe fruit rots in Queensland. Queensl. J. Agric. Sci. 22:437-459.

42. Smith, B. J., and Black, L. L. 1990. Morphological, cultural and pathogenic variation among Colletotrichum species isolated from strawberry. Plant Dis. 74:69-76.

43. Sreenivasaprasad, S., Sharada, K., Brown, A. E., and Mills, P. C. 1996. PCR-based detection of Colletotrichum acutatum on strawberry. Plant Pathol. 45:650-655.

44. Sreenivasaprasad, S., and Talhinhas, P. 2005. Genotypic and phenotypic diversity in Colletotrichum acutatum, a cosmopolitan pathogen causing anthracnose on a wide range of hosts. Mol. Plant Pathol. 6:361-378.

45. Stenlid, J., Karlsson, J., and Högberg, N. 1994. Intraspecific genetic variation in Heterobasidion annosum revealed by amplification of minisatellite DNA. Mycol. Res. 98:57-63.

46. Sutton, B. C. 1992. The genus Glomerella and its anamorph Colletotrichum. Pages 1-26 in: Colletotrichum: Biology, Pathology and Control. J. A. Bailey, and M. J. Jeger, eds. CAB International, Oxon, UK.

47. Talhinhas, P., Sreenivasaprasad, S., Neves-Martins, J., and Oliveira, H. 2002. Genetic and morphological characterization of Colletotrichum acutatum causing anthracnose of lupins. Phytopathology 92:986-996.

48. Talhinhas, P., Sreenivasaprasad, S., Neves-Martins, J., and Oliveira, H. 2005. Molecular and phenotypic analyses reveal association of diverse Colletotrichum acutatum groups and a low level of $C$. gloeosporioides with olive anthracnose. Appl. Environ. Microbiol. 71:2987-2998.

49. Tamura, K., Dudley, J., Nei, M., and Kumar, S. 2007. Molecular Evolutionary Genetics Analysis (MEGA) software, version 4.0. Mol. Biol. Evol. 24:1596-1599.

50. Van de Peer, Y., and De Wachter, R. 1994. TREECON for Windows: a software package for the construction and drawing of evolutionary trees for the Microsoft Windows environment. Comput. Appl. Biosci. CABIOS 10:569-570.

51. Waller, J. M. 1992. Colletotrichum diseases of perennial and other cash crops. Pages 167-185 in: Colletotrichum; Biology, Pathology and Control. J. A. Bailey, and M. J. Jeger, eds. CAB International, Oxon, UK.

52. Weining, S., and Langridge, P. 1991. Identification and mapping of polymorphisms in cereals based on polymerase chain reaction. Theor. Appl. Genet. 82:209-216.

53. White, T. J., Bruns, T., Lee, S., and Taylor, J. 1990. Amplification and direct sequencing of fungal ribosomal RNA genes for phylogenetics. Pages 315-322 in: PCR Protocols: A Guide to Methods and Applications. M. Innes, D. Gelfand, J. Sninsky, and T. White, eds. Academic Press, San Diego, CA.

54. Whitelaw-Weckert, M. A., Curtin, S. J., Huang, R., Steel, C. C., Blanchard, C. L., and Roffey, P. E. 2007. Phylogenetic relationships and pathogenicity of Colletotrichum acutatum isolates from grape in subtropical Australia. Plant Pathol. 56:448-463. 